\title{
Comparison of infliximab and ustekinumab for the treatment of moderate-to-severe psoriasis: an indirect comparison meta-analysis
}

This article was published in the following Dove Press journal:

Comparative Effectiveness Research

23 March 2015

Number of times this article has been viewed

Tao Fan'

Heather A Bennett ${ }^{2}$

Nancy E Smith ${ }^{3}$

Mihaela Marin ${ }^{2}$

Shuvayu Sankar Sen'

'Global Health Outcomes, Merck \& Co, Inc., Whitehouse Station, NJ, USA; ${ }^{2}$ Market Access, Reimbursement and Pricing, Optumlnsight, Burlington, Ontario, Canada; ${ }^{3}$ Access, Innovations and Operations, Merck \& Co, Inc., Whitehouse Station, NJ, USA
Correspondence: Tao Fan Global Health Outcomes, Merck \& Co, Inc., One Merck Drive, WS2E-76, Whitehouse Station, NJ, USA

Tel + I 9084234627

Fax + I 9087351688

Email tao.fan@merck.com
Objectives: As no direct comparisons have been made between infliximab and ustekinumab, the present study's aim was to estimate these drugs' relative efficacy in the treatment of moderate-to-severe psoriasis.

Methods: Eleven randomized controlled trials of infliximab $5 \mathrm{mg} / \mathrm{kg}$ and ustekinumab $45 \mathrm{mg}$ or $90 \mathrm{mg}$, reporting Psoriasis Area and Severity Index (PASI) 75 and PASI 90 end points, were identified from a systematic literature review. Of these, five were excluded because they had inappropriate intervention $(n=1)$, inappropriate patient population $(n=3)$, or a small sample size $(n=1)$. Ultimately, six studies were included in the networks. Log odds ratio (OR) of achieving PASI 75 or PASI 90 was used as the treatment effect in fixed- and random-effects mixed treatment comparison meta-analysis.

Results: Based on the results of the random-effects model, when compared to infliximab $5 \mathrm{mg} / \mathrm{kg}$, the OR of ustekinumab $90 \mathrm{mg}$ and ustekinumab $45 \mathrm{mg}$ achieving a PASI 75 following 12 weeks of treatment was $0.57 \mathrm{CrI}(0.19,1.29)$ and $0.44(0.15,0.99)$, respectively. Similarly, the odds of achieving PASI 90 was $0.77(0.09,2.70)$ for ustekinumab $90 \mathrm{mg}$ and $0.63(0.07$, 2.20) for ustekinumab $45 \mathrm{mg}$. Infliximab $5 \mathrm{mg} / \mathrm{kg}$ had the highest probability of being the most effective of all treatments considered, in attaining a PASI 75 (92\%) and PASI 90 response $(76 \%)$. Ustekinumab $90 \mathrm{mg}$ had the highest probability of being ranked second in attaining a PASI 75 (84\%) and PASI 90 response (62\%). Results from the random- and fixed-effects models were consistent.

Conclusion: A greater proportion of patients with plaque psoriasis are expected to achieve a PASI 75 or PASI 90 response when treated with infliximab $5 \mathrm{mg} / \mathrm{kg}$ than with ustekinumab $90 \mathrm{mg}$ or $45 \mathrm{mg}$.

Keywords: TNF inhibitor, Interleukin 12/23 inhibitor, biologic therapy, comparative effectiveness, randomized clinical trial, PASI score

\section{Introduction}

Plaque psoriasis is a chronic, inflammatory, autoimmune disorder that is thought to be due to an increased flux of leukocyte, specifically T-cells, to the dermis and epidermis. This influx induces increased cytokine production, altering the epidermal skin-cell cycle, and causing the skin to shed more frequently, ${ }^{1}$ resulting in raised patches of dead skin - the psoriatic plaques. ${ }^{1,2}$

Because of the primary role of T-cells in the pathology of psoriasis, biologic agents have been developed to target these cells and their functions. ${ }^{3,4}$ There are three monoclonal antibodies (adalimumab, infliximab and ustekinumab) and two circulating receptor fusion proteins (alefacept and etanercept) available for the treatment of plaque psoriasis in the United Kingdom and the United States. 
To the authors' knowledge, there have been no randomized controlled trials (RCTs) comparing all available biologic therapies, and the authors have used meta-analytic techniques to estimate the comparative efficacy and safety of these agents. ${ }^{5-11}$ Three meta-analyses ${ }^{10-12}$ did not include ustekinumab and three $e^{5,6,9}$ provided results of pairwise comparisons of active treatment with placebo, but did not present a comparative assessment of the efficacy or safety of the biologics. In a published meta-analysis that compared the efficacy of anti-TNFs in 2009, infliximab showed significantly superior efficacy than other anti-TNFs. While in a head to head randomized trial compared to etanercept, ustekinumab achieved better outcomes. ${ }^{13}$ However, a comparison between infliximab and ustekinumab has never been made, and hence there is a lack of knowledge and need for comparison of these two products in the literature. In 2009, the National Institute for Health and Clinical Excellence $(\mathrm{NICE})^{7}$ released a guidance document on the use of ustekinumab in the treatment of moderate-to-severe psoriasis that relied, in part, upon the results of an economic model that utilized data from a mixed treatment comparison of adalimumab, efalizumab, infliximab, and etanercept. However, the meta-analysis was not included in the guidance, and, to our knowledge, is not in the public domain. Recently, Reich et $\mathrm{al}^{8}$ used a probit model to estimate the comparative efficacy and probability of response of all biologics approved for the treatment of plaque psoriasis in Europe. With updated clinical trial information and a different method, the objective of this study is to compare the efficacy of infliximab $5 \mathrm{mg} / \mathrm{kg}$, ustekinumab $45 \mathrm{mg}$, and ustekinumab $90 \mathrm{mg}$ for the treatment of moderate-to-severe psoriasis in adults who have plaque psoriasis and provide an estimate of the efficacy ranking for each comparator by conducting a mixed-treatment comparison (MTC) meta-analysis.

\section{Materials and methods \\ Systematic literature search}

A systematic search of the electronic database PubMed, from database inception to April 5, 2011, was performed to identify evidence for inclusion in the meta-analysis. RCTs that reported the results of head-to-head or placebo-controlled comparisons of infliximab and ustekinumab were eligible for inclusion. Primary end points to measure efficacy of treatments included Psoriasis Area and Severity Index (PASI) 75 and PASI 90, while PASI 50 was not included. Studies must have provided baseline and end point, or baseline and change from baseline data (number or proportion of patients achieving PASI 75 or PASI 90 scores $^{14}$ ) and time of measurement (ie, weeks from baseline) for each outcome of interest. The search was limited to reports published in the English language (Table 1).

\section{Statistical analyses}

To allow synthesis of both direct (head-to-head) and indirect evidence from available RCTs, Bayesian meta-analytic techniques ${ }^{15}$ were used to perform an MTC meta-analysis. ${ }^{16}$ Outcomes were analyzed as binary data using both fixedeffects and random-effects models. ${ }^{15,17}$ The log odds ratio (OR) was used as the measure of treatment effect. The likelihood of achieving a PASI 75 or PASI 90 response was estimated using the pooled estimate for placebo as the reference treatment.

Models were fitted with Markov chain Monte Carlo (MCMC) techniques using WinBUGS version 1.4.3; MRC Biostatistics Unit, Cambridge, UK. ${ }^{18}$ Convergence was measured using the deviance information criterion (DIC), as proposed by Spiegelhalter et al. ${ }^{19}$ For analyses that included multi-arm trials, a correlation structure was included in the models. Consistency between indirect and direct evidence was explored by comparing the results of traditional metaanalyses of head-to-head comparisons to those of the network meta-analysis..$^{20} \mathrm{MCMC}$ sampling was used to estimate the probability of a treatment being superior to the others (ranking) using, as a proxy, the proportion of simulations where this situation was true.

Sensitivity analyses were conducted to explore the degree to which base case findings were affected by changes in methods, data from individual studies, or the choice of distributions for the vague priors, and stratifying patients by baseline PASI score.

Statistical heterogeneity was assessed using $\mathrm{I}^{2}$, the proportion of total variation in the estimates of treatment effect between studies. ${ }^{21}$ Higher values of $\mathrm{I}^{2}$ are evidence that a random effects model is preferable to a fixed effects model due to the heterogeneity present. ${ }^{21}$

\section{Table I Search strategy}

\begin{tabular}{|c|c|c|}
\hline$\# 1$ & Search "Psoriasis” [Mesh] OR “Arthritis, Psoriatic” [Mesh] & 25783 \\
\hline \#2 & $\begin{array}{l}\text { Search infliximab OR mab ca2 OR ustekinumab OR } \\
\text { cnto- } 1275 \text { OR briakinumab }\end{array}$ & 6602 \\
\hline \#3 & Search (psoriasis [Title]) OR psoriatic arthritis [Title] & 16334 \\
\hline$\# 4$ & Search \#I OR \#3 & 26755 \\
\hline \#5 & Search \#2 AND \#4 & 776 \\
\hline \#6 & $\begin{array}{l}\text { Search \#5 limits: randomized controlled trial, English, } \\
\text { all adult: } 19+\text { years }\end{array}$ & 34 \\
\hline
\end{tabular}

Note: cnto- 1275 is the experimental name for ustekinumab. Abbreviation: mab ca2, chimeric A2 monoclonal antibody. 
Due to the limited number of studies available for each comparison, the assessment of publication bias using funnel plots was not feasible.

\section{Results}

\section{Systematic literature review}

The literature search identified 34 studies, of which 12 were rejected: five were not RCTs, and seven did not report PASI 75 or PASI 90. Thus, 22 studies were available for potential inclusion in the review. Of those, 16 were excluded because they had an inappropriate outcome measure $(\mathrm{n}=8)$; inappropriate study design $(\mathrm{n}=2)$; were duplicate studies $(\mathrm{n}=1)$; reported an inappropriate intervention $(\mathrm{n}=1)$; included an inappropriate patient population $(n=3)$; or had a small sample size $(\leq 10)(\mathrm{n}=1)$ (Figure 1). Thus, six studies, ${ }^{22-27}$ three for infliximab, ${ }^{24,25,27}$ and three for ustekinumab ${ }^{22,23,26}$ (Table 2) were included in the networks (Figure 2).

Patients were between 35 and 46 years of age and there were slightly more males than females. All had plaque psoriasis with just less than $30 \%$ body surface area involvement. Disease duration ranged from 17 to 20 years, baseline PASI scores ranged from 19 to 22 , and between $22 \%$ and $37 \%$ of patients had a diagnosis of psoriatic arthritis. All patients had previous exposure to disease-modifying antirheumatic agents, and less than $30 \%$ had received biologics at some time prior to study entry. A single study ${ }^{27}$ reported that approximately $80 \%$ of patients had nail psoriasis. Individual study results are provided in Table 3.

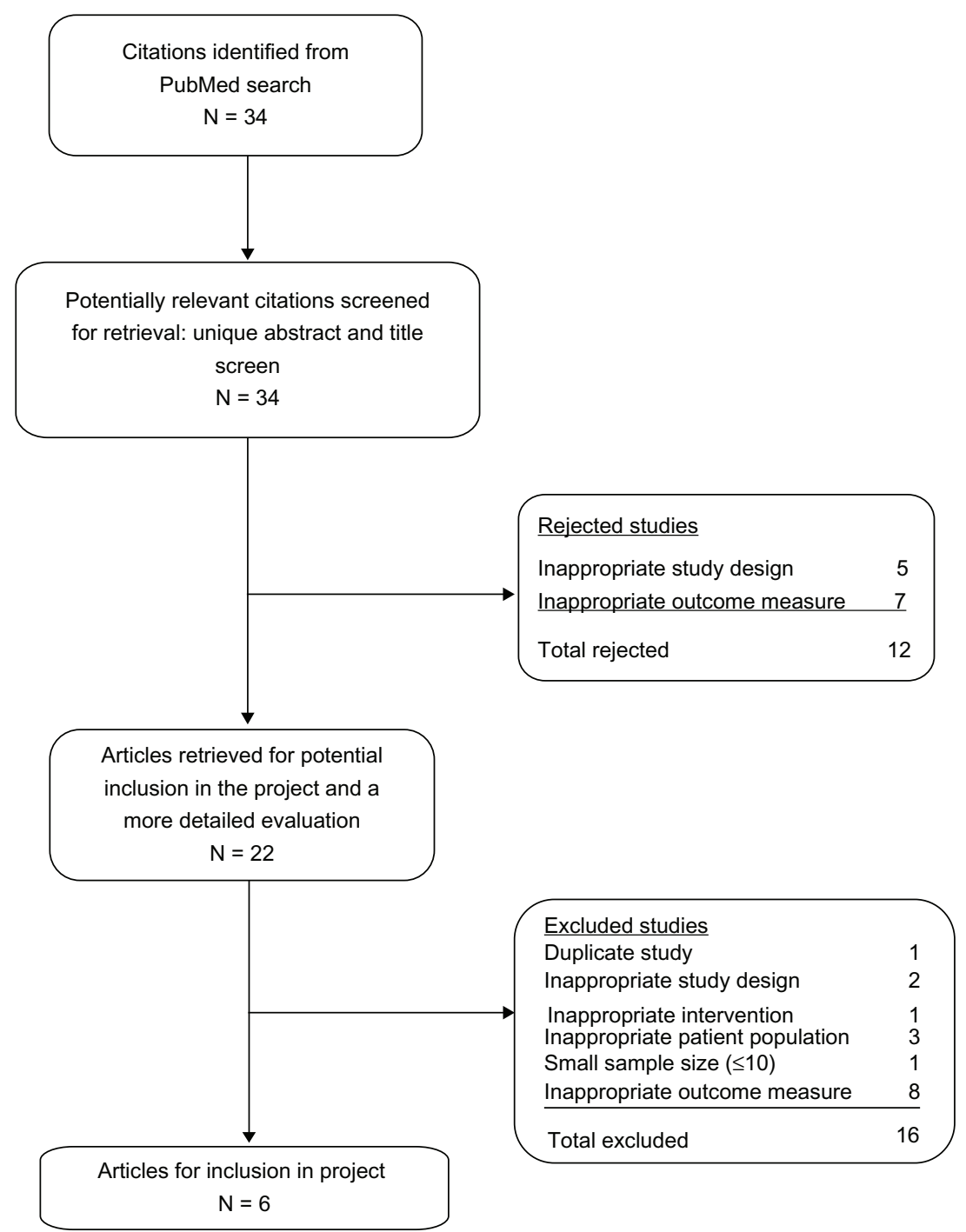

Figure I Flow diagram of study selection. 


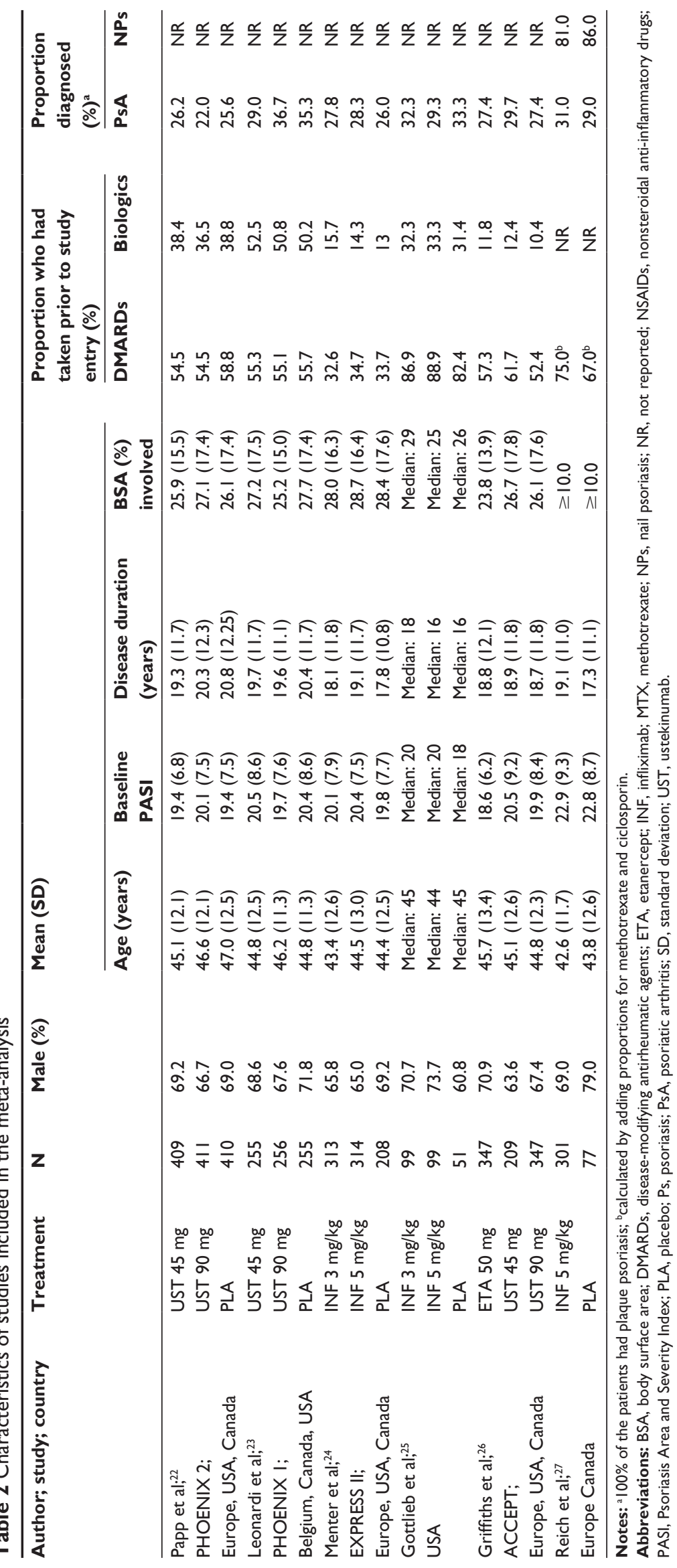




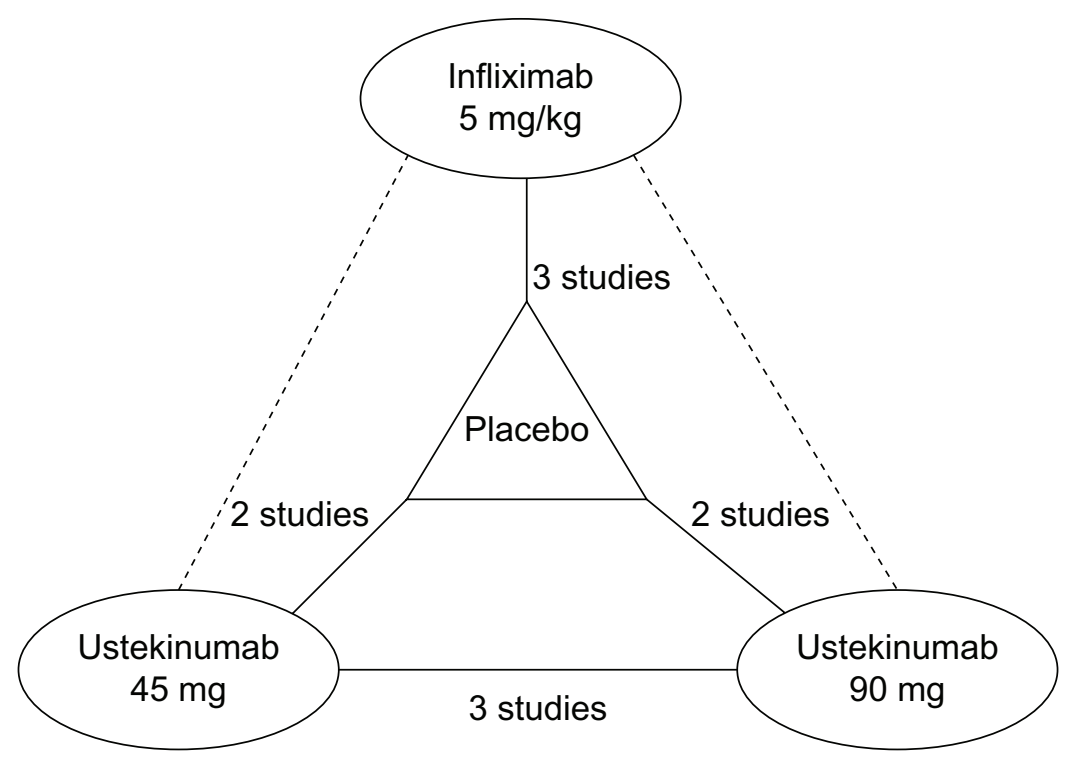

Figure 2 Network for comparison of selected biologics for the treatment of plaque psoriasis.

Note: Solid lines represent direct comparisons (ie, randomized controlled trial evidence), while dashed lines represent indirect comparisons (ie, generated by the model).

\section{Network meta-analysis}

PASI 75: pooled estimates of treatment effect

Infliximab $5 \mathrm{mg} / \mathrm{kg}$ and ustekinumab $45 \mathrm{mg}$ and $90 \mathrm{mg}$ were statistically significantly more effective than placebo in attaining a PASI 75 response when used for the treatment of plaque psoriasis. Results from the fixed- and random-effects models suggest that there is a statistically significant difference between infliximab $5 \mathrm{mg} / \mathrm{kg}$ and ustekinumab $45 \mathrm{mg}(\mathrm{OR}=0.42 ; 95 \%$ credible interval [CrI]: $0.16,0.87)$ and (OR $=0.44 ; 95 \%$ CrI: $0.15,0.99$, respectively). The comparison between infliximab $5 \mathrm{mg} /$ $\mathrm{kg}$ and ustekinumab $90 \mathrm{mg}$ did not, however, reach statistical significance in either model $(\mathrm{OR}=0.54 ; 95 \%$ CrI: $0.21,1.13$ for the fixed-effects model and $\mathrm{OR}=0.57$;
95\% CrI: $0.19,1.29$ for the random-effects model). Ustekinumab $90 \mathrm{mg}$ was statistically significantly more effective than ustekinumab $45 \mathrm{mg}$ in attaining a PASI 75 response in the fixed-effects model $(\mathrm{OR}=1.31 ; 95 \% \mathrm{CrI}$ : $1.07,1.59)$, though this result was not reflected in the random-effects model (Table 4).

Of all treatments considered, infliximab $5 \mathrm{mg} / \mathrm{kg}$ had the greatest probability $(95 \%$ in the fixed-effects model, and $92 \%$ in the random-effects model) of ranking as the most effective treatment for attaining a PASI 75. Ustekinumab $90 \mathrm{mg}$ ranked second $(95 \%$ in the fixed-effects model and $84 \%$ in the random-effects model), and ustekinumab $45 \mathrm{mg}$ ranked third (99\% in the fixed-effects model and $89 \%$ in the random-effects model). Placebo were the least

Table 3 Efficacy results of studies included in the meta-analysis

\begin{tabular}{|c|c|c|c|c|c|c|c|c|c|}
\hline \multicolumn{2}{|l|}{ Study details } & \multicolumn{8}{|c|}{ Proportion of patients achieving } \\
\hline \multirow[t]{3}{*}{ Author; year; trial } & \multirow{3}{*}{$\begin{array}{l}\text { Time for endpoint } \\
\text { measurement } \\
\text { (weeks) }\end{array}$} & \multicolumn{4}{|c|}{ PASI 75} & \multicolumn{4}{|c|}{ PASI 90} \\
\hline & & PLA & INF & UST & UST & PLA & INF & UST & UST \\
\hline & & & $\overline{5 \mathrm{mg} / \mathrm{kg}}$ & $45 \mathrm{mg}$ & $\overline{90 \mathrm{mg}}$ & & $\overline{5 \mathrm{mg} / \mathrm{kg}}$ & $45 \mathrm{mg}$ & $\overline{90 \mathrm{mg}}$ \\
\hline $\begin{array}{l}\text { Papp et al:;22 2008; } \\
\text { PHOENIX } 2\end{array}$ & 12 & $15 / 410$ & & $273 / 409$ & $3|I / 4| \mid$ & $3 / 410$ & & $173 / 409$ & $209 / 411$ \\
\hline $\begin{array}{l}\text { Leonardi et al; }{ }^{23} 2008 \text {; } \\
\text { PHOENIX I }\end{array}$ & 12 & $8 / 255$ & & $17 \mid / 255$ & $170 / 256$ & $5 / 255$ & & $106 / 255$ & $94 / 256$ \\
\hline $\begin{array}{l}\text { Menter et al:; }{ }^{24} 2007 ; \\
\text { EXPRESS II }\end{array}$ & 10 & $4 / 208$ & $237 / 314$ & & & $1 / 208$ & $|42 / 3| 4$ & & \\
\hline Gottlieb et al; 252004 & 10 & $3 / 51$ & $86 / 99$ & & & $1 / 51$ & $57 / 99$ & & \\
\hline $\begin{array}{l}\text { Griffiths et al:26 20I0; } \\
\text { ACCEPT }\end{array}$ & 12 & & & $|4| / 209$ & $256 / 347$ & & & $76 / 209$ & $155 / 347$ \\
\hline Reich et al;;27 2005 & 10 & $2 / 77$ & $24 I / 301$ & & & $\mathrm{I} / 77$ & $|72 / 30|$ & & \\
\hline
\end{tabular}

Abbreviations: INF, infliximab; PASI, Psoriasis Area and Severity Index; PLA, placebo; UST, ustekinumab. 
Table 4 Likelihood of achieving the desired outcome, by treatment comparison

\begin{tabular}{|c|c|c|c|c|}
\hline \multirow[t]{3}{*}{ Intervention } & \multicolumn{4}{|c|}{ Odds ratio $\left(95 \% \mathrm{CrI}^{\mathrm{a}}\right)$ for achieving PASI 75 or PASI 90} \\
\hline & \multirow[t]{2}{*}{ Placebo } & Infliximab & \multirow{2}{*}{$\frac{\text { Ustekinumab }}{45 \mathrm{mg}}$} & \multirow{2}{*}{$\frac{\text { Ustekinumab }}{90 \mathrm{mg}}$} \\
\hline & & $5 \mathrm{mg} / \mathrm{kg}$ & & \\
\hline \multicolumn{5}{|c|}{ PASI 75 fixed-effects model } \\
\hline Placebo & I & & & \\
\hline Infliximab 5 mg & $164.40(78.35,330.10)$ & 1 & & \\
\hline Ustekinumab $45 \mathrm{mg}$ & $59.76(37.89,92.25)$ & $0.42(0.16,0.87)$ & I & \\
\hline Ustekinumab $90 \mathrm{mg}$ & $77.89(49.34,121.10)$ & $0.54(0.21,1.13)$ & $1.31(1.07,1.59)$ & 1 \\
\hline \multicolumn{5}{|c|}{ PASI 75 random-effects model } \\
\hline Placebo & I & & & \\
\hline Infliximab 5 mg & $164.60(71.35,339.10)$ & I & & \\
\hline Ustekinumab $45 \mathrm{mg}$ & $61.2(32.33,107.00)$ & $0.44(0.15,0.99)$ & I & \\
\hline Ustekinumab 90 mg & $78.96(41.98,136.90)$ & $0.57(0.19,1.29)$ & $1.33(0.79,2.10)$ & 1 \\
\hline \multicolumn{5}{|c|}{ PASI 90 fixed-effects model } \\
\hline Placebo & I & & & \\
\hline Infliximab 5 mg & $172.60(46.69,525.20)$ & 1 & & \\
\hline Ustekinumab 45 mg & $65.45(32.10,127.80)$ & $0.56(0.10,1.63)$ & I & \\
\hline Ustekinumab 90 mg & $79.61(39.24,155.20)$ & $0.69(0.12,2.00)$ & $1.22(1.01,1.47)$ & 1 \\
\hline \multicolumn{5}{|c|}{ PASI 90 random-effects model } \\
\hline Placebo & I & & & \\
\hline Infliximab 5 mg & $192.10(41.62,676.70)$ & I & & \\
\hline Ustekinumab 45 mg & $69.93(22.79,167.40)$ & $0.63(0.07,2.20)$ & I & \\
\hline Ustekinumab 90 mg & $85.79(27.76,208.30)$ & $0.77(0.09,2.70)$ & $1.35(0.52,2.93)$ & 1 \\
\hline
\end{tabular}

Notes: Comparison is for rows versus columns, eg, a greater proportion of patients will achieve PASI 75 with infliximab $5 \mathrm{mg} / \mathrm{kg}$ (row 2) than with placebo (column I). ${ }^{a} \mathrm{Crls}$ are analogous to confidence intervals in frequentist statistics.

Abbreviations: $\mathrm{Crl}$, credible interval; PASI, psoriasis area and severity index.

effective, in both random- and fixed-effects models (Table 5; Figure 3).

\section{PASI 90: pooled estimates of treatment effect}

Results from both the fixed- and random-effects models showed no statistically significant difference between infliximab $5 \mathrm{mg} / \mathrm{kg}$ and either of the two ustekinumab doses for the attainment of a PASI 90 response $(\mathrm{OR}=0.56$; 95\% CrI: 0.10, 1.63 and OR $=0.63$; 95\% CrI: 0.07, 2.20, respectively, for infliximab $5 \mathrm{mg} / \mathrm{kg}$ versus ustekinumab $45 \mathrm{mg}$, and $\mathrm{OR}=0.69 ; 95 \% \mathrm{CrI}: 0.12,2.00$ and $\mathrm{OR}=0.77$; $95 \%$ CrI: $0.09,2.70$, respectively, for infliximab $5 \mathrm{mg} / \mathrm{kg}$ versus ustekinumab $90 \mathrm{mg}$ ). Consistent with the PASI 75 results, ustekinumab $90 \mathrm{mg}$ was statistically significantly more effective than ustekinumab $45 \mathrm{mg}$ in attaining a PASI 90 response in the fixed-effects model (OR $=1.22 ; 95 \% \mathrm{CrI}: 1.01,1.47)$, but not the random-effects model; however, it is unlikely that this difference is clinically significant (Table 4).

Infliximab $5 \mathrm{mg} / \mathrm{kg}$ had a probability of $80 \%$ in the fixed-effect model and $76 \%$ in the random-effects model of being the most effective treatment in attaining a PASI 90 response. Ustekinumab $90 \mathrm{mg}$ had a probability of $79 \%$ and $62 \%$ of being ranked second in the fixed- and randomeffects models, respectively. Finally, ustekinumab $45 \mathrm{mg}$ had probabilities of $86 \%$ and $67 \%$ of being ranked third in the fixed- and random-effects models, respectively (Table 5; Figure 3).

\section{Consistency and comparisons between models}

Results of the MTC MAs were consistent with those derived from traditional meta-analyses of infliximab versus placebo, ustekinumab $45 \mathrm{mg}$ versus placebo, and ustekinumab $90 \mathrm{mg}$ versus placebo, for both PASI 75 and PASI 90 measurements (Tables S1-S4).

A comparison of the results of MTC meta-analyses run with and without the correlation structure showed no appreciable differences (Table S5).

DICs for the fixed- and random-effects models were comparable. For PASI 75, the DIC for the fixed-effects model was 91.089 compared to 91.744 for the random-effects models. The residual deviance values were 13.05 and 11.78 , respectively. For PASI 90, the DIC was 94.692 and 92.052 for fixed- and random-effects models, respectively, and residual deviance values were 19.27 and 14.05 , respectively.

\section{Sensitivity analyses}

Sensitivity analyses explored the use of uniform, logistic, and double exponential distributions as priors. Sensitivity analyses results were consistent with those of the base case estimates. Due to the limited number of studies, a sensitivity 
Table 5 Ranking of interventions: probability of efficacy, by PASI

\begin{tabular}{|c|c|c|c|c|}
\hline \multirow[t]{3}{*}{ Rank } & \multicolumn{4}{|c|}{ Expected efficacy rankings } \\
\hline & \multirow{2}{*}{$\frac{\text { Infliximab }}{5 \mathrm{mg} / \mathrm{kg}}$} & \multicolumn{2}{|c|}{ Ustekinumab } & \multirow[t]{2}{*}{ Placebo } \\
\hline & & $90 \mathrm{mg}$ & $45 \mathrm{mg}$ & \\
\hline \multicolumn{5}{|c|}{ PASI 75 fixed-effects model } \\
\hline 1 & 0.95 & 0.05 & 0 & 0 \\
\hline 2 & 0.04 & 0.95 & 0.01 & 0 \\
\hline 3 & 0.01 & 0 & 0.99 & 0 \\
\hline 4 & 0 & 0 & 0 & I \\
\hline \multicolumn{5}{|c|}{ PASI 75 random-effects model } \\
\hline 1 & 0.92 & 0.07 & 0.01 & 0 \\
\hline 2 & 0.06 & 0.84 & 0.1 & 0 \\
\hline 3 & 0.02 & 0.09 & 0.89 & 0 \\
\hline 4 & 0 & 0 & 0 & 1 \\
\hline \multicolumn{5}{|c|}{ PASI 90 fixed-effects model } \\
\hline I & 0.8 & 0.2 & 0 & 0 \\
\hline 2 & 0.07 & 0.79 & 0.14 & 0 \\
\hline 3 & 0.13 & 0.02 & 0.86 & 0 \\
\hline 4 & 0 & 0 & 0 & I \\
\hline \multicolumn{5}{|c|}{ PASI 90 random-effects model } \\
\hline I & 0.76 & 0.19 & 0.05 & 0 \\
\hline 2 & 0.11 & 0.62 & 0.27 & 0 \\
\hline 3 & 0.14 & 0.19 & 0.67 & 0 \\
\hline 4 & 0 & 0 & 0 & I \\
\hline
\end{tabular}

Abbreviation: PASI, psoriasis area and severity index.

A: PASI 75 fixed-effects model - efficacy ranking

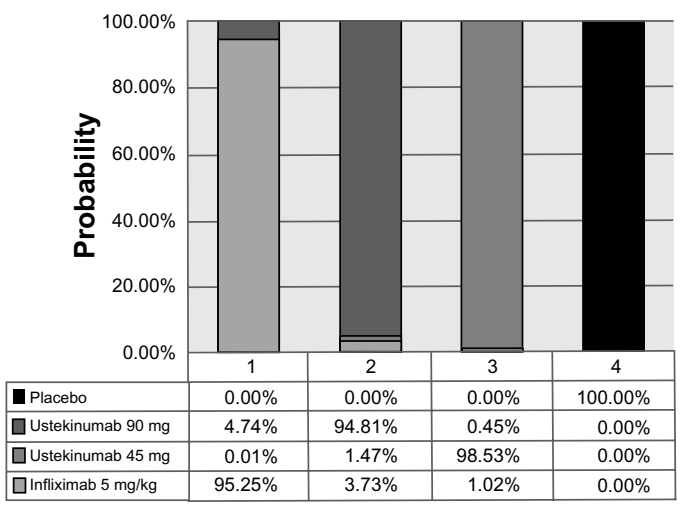

C: PASI 90 fixed-effects model - efficacy ranking

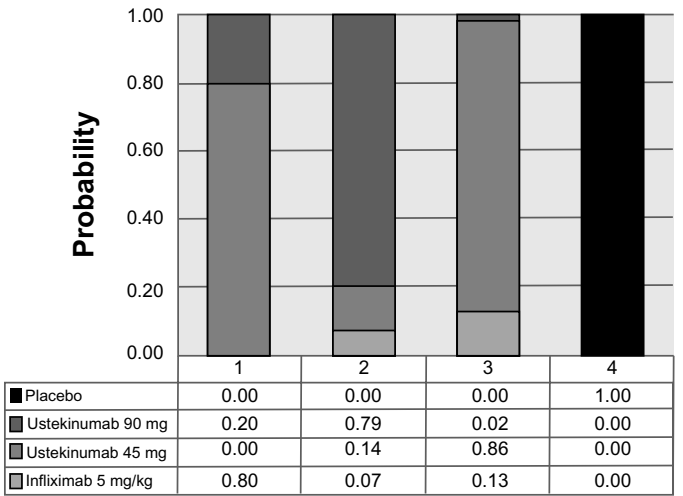

analysis to examine the effect of stratification of studies by mean baseline PASI score was not feasible.

\section{Heterogeneity}

Notable heterogeneity was observed for comparisons of placebo and either dose of ustekinumab for the PASI 90, and for comparisons between the ustekinumab dosages for both PASI 75 and PASI $90\left(\mathrm{I}^{2}>46 \%\right)$. Infliximab shows consistent treatment effects across studies for both the PASI 75 and PASI 90.

\section{Discussion}

The results of this MTC meta-analysis suggest that infliximab $5 \mathrm{mg} / \mathrm{kg}$ is likely to be more effective in attaining a PASI response than ustekinumab $90 \mathrm{mg}$ or $45 \mathrm{mg}$ in the treatment of moderate-to-severe psoriasis. Results from the fixed- and random-effects models found that infliximab had the greatest probability (92\% and 95\%, respectively) of ranking as the most effective treatment for attaining a PASI 75. Ustekinumab $90 \mathrm{mg}$ had a probability of $95 \%$ and $84 \%$, respectively, of ranking second, and ustekinumab $45 \mathrm{mg}$ ranked third $(99 \%$

B: PASI 75 random-effects model - efficacy ranking

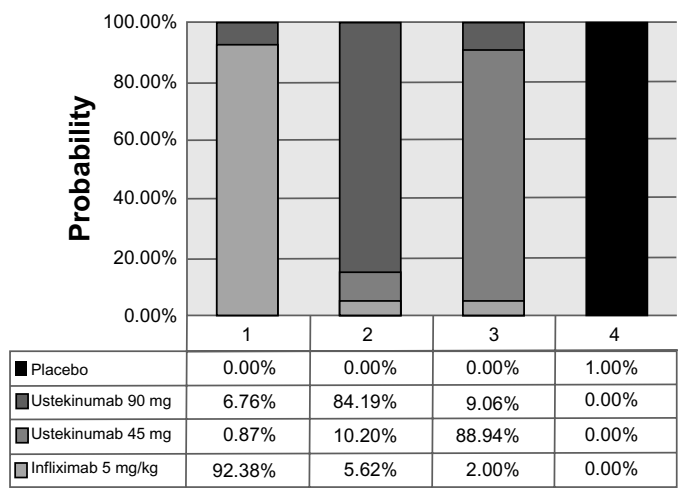

D: PASI 90 random-effects model - efficacy ranking

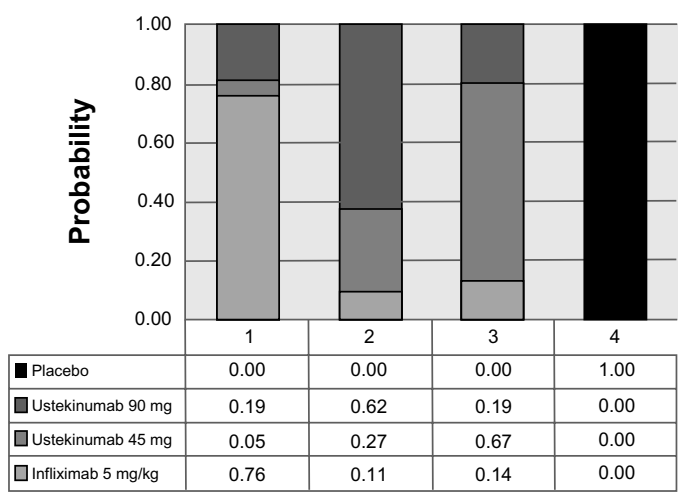

Figure 3 Probabilities of treatment rankings: efficacy according to PASI response. Efficacy rankings of (A) PASI 75 fixed-effects model; (B) PASI 75 random-effects model; (C) PASI 90 fixed-effects model; and (D) PASI 90 random-effects model - efficacy ranking.

Abbreviation: PASI, psoriasis area and severity index. 
and $89 \%$, respectively). This result is similar to that of other published analyses that have included ustekinumab. ${ }^{7,8}$

Reich et $\mathrm{al}^{8}$ estimated that infliximab had a probability of $93 \%$ being the most efficacious treatment in attaining a PASI 75; ustekinumab $90 \mathrm{mg}$ a probability of $81 \%$ of ranking second; and ustekinumab $45 \mathrm{mg}$ a probability of $79 \%$ of ranking third. In addition, they estimated that infliximab $5 \mathrm{mg} / \mathrm{kg}$ had the highest probability of achieving a PASI 50 (93\%), PASI 75 (80\%), and PASI 90 (55\%) response, followed by ustekinumab $90 \mathrm{mg}$, ustekinumab $45 \mathrm{mg}$, adalimumab, etanercept, and efalizumab.

Overall, traditional and MTC meta-analytic estimates suggest that infliximab is likely to be the most efficacious of all the biologics for the treatment of psoriasis. These results, consistent with previous analyses, reinforced the efficacy of infliximab in psoriasis management. It is also confirmed that, although ustekinumab demonstrated statistically significant better outcomes than etanercept in one randomized clinical trial, this conclusion cannot be extended to the entire anti-TNF class. In addition, the ranking of the efficacy of all biologic therapies in psoriasis management will inform clinicians and policy makers about treatment and formulary decisions.

The main limitation of our MTC meta-analysis is the small number of RCTs available for inclusion in the networks. Thus, all estimates have wide confidence and credible intervals. However, analyses were based on the results of a systematic literature review, and it is unlikely that additional evidence on those comparators was available at the time of the search.

A search of the registry at ClinicalTrials.gov (http:// clinicaltrials.gov/) revealed that additional data is likely to be available in the future. As more research data becomes available on the efficacy of infliximab and ustekinumab, updated MTCs will produce more precise estimates. More precise estimates may also be possible if the networks are expanded by including other biologic treatments.

A second limitation is that there was no attempt to locate data from unpublished studies. Research with statistically significant results is more likely to be published than work with null or nonsignificant results (publication bias), which may lead to overly optimistic and incorrect results. ${ }^{16}$

Third, RCTs included in the analyses reported outcomes at 10-12 weeks of therapy, and long-term outcomes were not available. This may be important, as plaque psoriasis is a chronic condition and biologics are likely to be prescribed on an ongoing basis. Notably, Reich et $\mathrm{al}^{12}$ have reported that significant differences between biological treatments appear to be attenuated at 24 weeks' postinitiation of therapy.

Finally, the prescribing label of ustekinumab stipulates that patients weighing over $100 \mathrm{~kg}$ will be treated with $90 \mathrm{mg}$ therapy, while patients under $100 \mathrm{~kg}$ of weight will take $45 \mathrm{mg} .{ }^{28}$ In the clinical trials of ustekinumab, ${ }^{29,30,31}$ however, the weight-based analyses were not reported, and it is therefore not possible to derive the results for the $45 \mathrm{mg}$ and 90 mg ustekinumab for patients group with body weight under $100 \mathrm{~kg}$ or over $100 \mathrm{~kg}$.

\section{Conclusion}

Based on this meta-analysis, patients with moderate-to-severe plaque psoriasis who are treated with infliximab $5 \mathrm{mg} / \mathrm{kg}$ are more likely than those treated with ustekinumab $90 \mathrm{mg}$ and ustekinumab 45 to achieve a PASI 75 or PASI 90 response.

\section{Disclosure}

This research was supported by Merck \& Co, Inc., Whitehouse Station, NJ, USA. HB, NES, MM declare no conflict of interest. TF and SSS are employees of Merck \& Co, Inc.

\section{References}

1. Nair RP, Stuart PE, Nistor I, et al. Sequence and haplotype analysis supports HLA-C as the psoriasis susceptibility 1 gene. Am J Hum Genet. 2006;78:827-851.

2. Luba KM, Stulberg DL. Chronic plaque psoriasis. Am Fam Physician. 2006;73:636-644.

3. Menter A, Gottlieb A, Feldman SR, et al. Guidelines of care for the management of psoriasis and psoriatic arthritis: Section 1. Overview of psoriasis and guidelines of care for the treatment of psoriasis with biologics. J Am Acad Dermatol. 2008;58:826-850.

4. Emer JJ, Frankel A, Zeichner JA. A practical approach to monitoring patients on biological agents for the treatment of psoriasis. J Clin Aesthet Dermatol. 2010;3:20-26.

5. Schmitt J, Zhang Z, Wozel G, Meurer M, Kirch W. Efficacy and tolerability of biologic and nonbiologic systemic treatments for moderateto-severe psoriasis: meta-analysis of randomized controlled trials. Br J Dermatol. 2008;159:513-526.

6. Brimhall AK, King LN, Licciardone JC, Jacobe H, Menter A. Safety and efficacy of alefacept, efalizumab, etanercept and infliximab in treating moderate to severe plaque psoriasis: a meta-analysis of randomized controlled trials. Br J Dermatol. 2008;159:274-285.

7. Ustekinumab for the Treatment of Adults with Moderate to Severe Psoriasis. National Institute for Health and Clinical Excellence; 2009 [cited January 6, 2011]. Available from: http://www.nice.org.uk/ nicemedia/live/12235/45461/45461.pdf. Accessed March 20, 2013.

8. Reich K, Burden AD, Eaton JN, Hawkins NS. Efficacy of biologics in the treatment of moderate to severe psoriasis: a network metaanalysis of randomized controlled trials. Br J Dermatol. 2012;166: 179-188.

9. Zhang Z, Schmitt J, Wozel G, Kirch W. Behandlung der PlaquePsoriasis mit Biologics. [Treatment of plaque psoriasis with biologics. A meta-analysis of randomized controlled trials.] Med Klin (Munich). 2009;104:125-136. German. 
10. Woolacott N, Hawkins N, Mason A, et al. Etanercept and efalizumab for the treatment of psoriasis: a systematic review. Health Technol Assess. 2006;10:1-233, i-iv.

11. Bansback N, Sizto S, Sun H, Feldman S, Willian MK, Anis A. Efficacy of systemic treatments for moderate to severe plaque psoriasis: systematic review and meta-analysis. Dermatology. 2009;219:209-218.

12. Reich K, Sinclair R, Roberts G, Griffiths CE, Tabberer M, Barker J. Comparative effects of biological therapies on the severity of skin symptoms and health-related quality of life in patients with plaquetype psoriasis: a meta-analysis. Curr Med Res Opin. 2008;24: 1237-1254.

13. Griffiths CE, Strober BE, van de Kerkhof P, Ho V, Fidelus-Gort R, Yeilding $\mathrm{N}$ et al; ACCEPT Study Group. Comparison of ustekinumab and etanercept for moderate-to-severe psoriasis. $N \mathrm{Engl} \mathrm{J} \mathrm{Med.}$ 2010;362(2):118-28..

14. Feldman SR, Krueger GG. Psoriasis assessment tools in clinical trials. Ann Rheum Dis. 2005;64 Suppl 2:ii65-ii68; discussion ii69-ii73.

15. Spiegelhalter DJ, Abrams KR, Myles JP. Bayesian Approaches to Clinical Trials and Health-Care Evaluation. Chichester: John Wiley \& Sons, Ltd; 2004.

16. Sutton AJ, Abrams KR, Jones DR, Sheldon TA, Song F. Methods for Meta-Analysis in Medical Research. Chichester: John Wiley \& Sons, Ltd; 2000.

17. Borenstein M, Hedges LV, Higgins JPT, Rothstein HR. Introduction to Meta-Analysis. Chichester: John Wiley \& Sons, Ltd; 2009.

18. Lunn DJ, Thomas A, Best N, Spiegelhalter D. WinBUGS - a Bayesian modelling framework: concepts, structure, and extensibility. Stat Comput. 2000;10:325-337.

19. Spiegelhalter DJ, Best NG, Carlin BP, Van Der Linde A. Bayesian measures of model complexity and fit. JR Stat Soc Series B Stat Methodol. 2002;64:583-639.

20. Gelman A, Carlin JB, Stern HS, Rubin DB. Bayesian Data Analysis. Boca Raton, FL: Chapman and Hall/CRC; 2004.

21. Higgins JP, Thompson SG. Quantifying heterogeneity in a meta-analysis. Stat Med. 2002;21:1539-1558.

22. Papp KA, Langley RG, Lebwohl M, et al; PHOENIX 2 study investigators. Efficacy and safety of ustekinumab, a human interleukin-12/23 monoclonal antibody, in patients with psoriasis: 52-week results from a randomised, double-blind, placebo-controlled trial (PHOENIX 2). Lancet. 2008;371:1675-1684.
23. Leonardi CL, Kimball AB, Papp KA, et al; PHOENIX 1study investigators. Efficacy and safety of ustekinumab, a human interleukin-12/23 monoclonal antibody, in patients with psoriasis: 76-week results from a randomised, double-blind, placebo-controlled trial (PHOENIX 1). Lancet. 2008;371:1665-1674.

24. Menter A, Feldman SR, Weinstein GD, et al. A randomized comparison of continuous vs intermittent infliximab maintenance regimens over 1 year in the treatment of moderate-to-severe plaque psoriasis. $J \mathrm{Am}$ Acad Dermatol. 2007;56(1):31. e1-e15.

25. Gottlieb AB, Evans R, Li S, et al. Infliximab induction therapy for patients with severe plaque-type psoriasis: a randomized, double-blind, placebo-controlled trial. J Am Acad Dermatol. 2004;51:534-542.

26. Griffiths CE, Strober BE, van de Kerkhof P, et al; ACCEPT Study Group. Comparison of ustekinumab and etanercept for moderate-to-severe psoriasis. N Engl J Med. 2010;362:118-128.

27. Reich K, Nestle FO, Papp K, et al; EXPRESS study investigators. Infliximab induction and maintenance therapy for moderate-to-severe psoriasis: a phase III, multicentre, double-blind trial. Lancet. 2005;366: 1367-1374.

28. STELARA ${ }^{\circledR}$ [package insert]. Horsham, PA, USA; Janssen Biotech, Inc.; 2012. Available from: http://www.stelarainfo.com/pdf/PrescribingInformation.pdf. Accessed November 21, 2013.

29. Papp KA, Langley RG, Lebwohl M, Krueger GG, Szapary P, Yeilding N, Guzzo C, Hsu MC, Wang Y, Li S, Dooley LT, Reich K; PHOENIX 2 study investigators. Efficacy and safety of ustekinumab, a human interleukin-12/23 monoclonal antibody, in patients with psoriasis: 52-week results from a randomised, double-blind, placebo-controlled trial (PHOENIX 2). Lancet. 2008 May 17;371(9625):1675-84.

30. Griffiths CE, Strober BE, van de Kerkhof P, Ho V, Fidelus-Gort R, Yeilding N, Guzzo C, Xia Y, Zhou B, Li S, Dooley LT, Goldstein NH, Menter A; ACCEPT Study Group. Comparison of ustekinumab and etanercept for moderate-to-severe psoriasis. $N$ Engl J Med. 2010;362(2):118-28.

31. Leonardi CL, Kimball AB, Papp KA, Yeilding N, Guzzo C, Wang Y, Li S, Dooley LT, Gordon KB; PHOENIX 1 study investigators. Efficacy and safety of ustekinumab, a human interleukin-12/23 monoclonal antibody, in patients with psoriasis: 76-week results from a randomised, double-blind, placebo-controlled trial (PHOENIX 1). Lancet. 2008 May 17;371(9625):1665-74. 


\section{Supplementary tables}

Table SI Comparison of MTC MA and traditional MA results for infliximab and ustekinumab relative to placebo (PASI 75, MTC fixedeffects models)

\begin{tabular}{lllll}
\hline $\begin{array}{l}\text { Treatment effect } \\
\text { versus placebo }\end{array}$ & $\begin{array}{l}\text { Number } \\
\text { of trials }\end{array}$ & $\begin{array}{l}\text { Number } \\
\text { of patients }\end{array}$ & $\begin{array}{l}\text { Direct estimates } \\
\text { (traditional meta-analyses) }\end{array}$ & $\begin{array}{l}\text { MTC estimates } \\
\text { (95\% Crl) }\end{array}$ \\
\hline Infliximab 5 mg & 3 & 1050 & $143.86(70.57,293.27)$ & $164.4(78.35,330.1)$ \\
Ustekinumab 45 mg & 2 & 1916 & $56.32(36.04,87.99)$ & $59.76(37.89,92.25)$ \\
Ustekinumab 90 mg & 2 & 1679 & $73.04(46.49,114.77)$ & $77.89(49.34,121.1)$ \\
\hline
\end{tabular}

Abbreviations: $\mathrm{Crl}$, credible interval; MA, meta-analysis; MTC, mixed-treatment comparison; PASl, psoriasis area and severity index.

Table S2 Comparison of results from the traditional and MTC meta-analyses for infliximab and ustekinumab relative to placebo (PASI 75, MTC random-effects models)

\begin{tabular}{lllll}
\hline $\begin{array}{l}\text { Treatment effect } \\
\text { versus placebo }\end{array}$ & $\begin{array}{l}\text { Number } \\
\text { of trials }\end{array}$ & $\begin{array}{l}\text { Number } \\
\text { of patients }\end{array}$ & $\begin{array}{l}\text { Direct estimates } \\
\text { (traditional meta-analyses) }\end{array}$ & $\begin{array}{l}\text { MTC estimates } \\
\text { (95\% Crl) }\end{array}$ \\
\hline Infliximab 5 mg & 3 & 1050 & $138.68(68.76,279.68)$ & $164.6(71.35,339.1)$ \\
Ustekinumab 45 mg & 2 & 1916 & $56.20(35.96,87.81)$ & $61.2(32.33,107)$ \\
Ustekinumab 90 mg & 2 & 1679 & $73.67(46.97,115.56)$ & $78.96(41.98,136.9)$ \\
\hline
\end{tabular}

Abbreviations: $\mathrm{Crl}$, credible interval; MTC, mixed-treatment comparison; PASl, psoriasis area and severity index.

Table S3 Comparison of results from the traditional and MTC meta-analyses for infliximab and ustekinumab relative to placebo (PASI 90, MTC fixed-effects models)

\begin{tabular}{lllll}
\hline $\begin{array}{l}\text { Treatment effect } \\
\text { versus placebo }\end{array}$ & $\begin{array}{l}\text { Number } \\
\text { of trials }\end{array}$ & $\begin{array}{l}\text { Number } \\
\text { of patients }\end{array}$ & $\begin{array}{l}\text { Direct estimates } \\
\text { (traditional meta-analyses) }\end{array}$ & $\begin{array}{l}\text { MTC estimates } \\
\text { (95\% Crl) }\end{array}$ \\
\hline Infliximab 5 mg & 3 & 672 & $115.58(36.36,367.40)$ & $172.6(46.69,525.2)$ \\
Ustekinumab 45 mg & 2 & 1916 & $59.32(29.04,121.16)$ & $65.45(32.1,127.8)$ \\
Ustekinumab 90 mg & 2 & 1679 & $64.39(31.88,130.06)$ & $79.61(39.24,155.2)$ \\
\hline
\end{tabular}

Abbreviations: $\mathrm{Crl}$, credible interval; MTC, mixed-treatment comparison; PASl, psoriasis area and severity index.

Table S4 Comparison of results from the traditional and MTC meta-analyses for infliximab and ustekinumab relative to placebo (PASI 90, MTC random-effects models)

\begin{tabular}{lllll}
\hline $\begin{array}{l}\text { Treatment effect } \\
\text { versus placebo }\end{array}$ & $\begin{array}{l}\text { Number } \\
\text { of trials }\end{array}$ & $\begin{array}{l}\text { Number } \\
\text { of patients }\end{array}$ & $\begin{array}{l}\text { Direct estimates } \\
\text { (traditional meta-analyses) }\end{array}$ & $\begin{array}{l}\text { MTC estimates } \\
\text { (95\% Crl) }\end{array}$ \\
\hline Infliximab 5 mg & 3 & 672 & $106.19(33.58,335.76)$ & $192.1(41.62,676.7)$ \\
Ustekinumab 45 mg & 2 & 1916 & $56.11(20.12,156.48)$ & $69.93(22.79,167.4)$ \\
Ustekinumab 90 mg & 2 & 1679 & $61.47(12.58,300.28)$ & $85.79(27.76,208.3)$ \\
\hline
\end{tabular}

Abbreviations: $\mathrm{Crl}$, credible interval; MTC, mixed-treatment comparison; PASI, psoriasis area and severity index. 
Table S5 Results of analyses with and without adjustment for correlation (PASI 75)

\begin{tabular}{|c|c|c|}
\hline \multirow[t]{2}{*}{ Comparison } & \multicolumn{2}{|l|}{ OR (Crl) } \\
\hline & No correlation & Correlation \\
\hline \multicolumn{3}{|l|}{ Fixed-effects model } \\
\hline Infliximab $5 \mathrm{mg}$ vs placebo & I $64.4(78.35,330.1)$ & $164.4(78.35,330.1)$ \\
\hline Ustekinumab $45 \mathrm{mg}$ vs placebo & $59.76(37.89,92.25)$ & $59.76(37.89,92.25)$ \\
\hline Ustekinumab $90 \mathrm{mg}$ vs placebo & $77.89(49.34,121.1)$ & $77.89(49.34,121.1)$ \\
\hline Ustekinumab $45 \mathrm{mg}$ vs infliximab $5 \mathrm{mg}$ & $0.4 I 62(0.1606,0.867 I)$ & $0.4 I 62(0.1606,0.867 I)$ \\
\hline Ustekinumab 90 mg vs infliximab 5 mg & $0.5422(0.2093,1.128)$ & $0.5422(0.2093,1.128)$ \\
\hline Ustekinumab 90 mg vs ustekinumab 45 mg & $1.31(1.067,1.591)$ & $1.31(1.067,1.591)$ \\
\hline \multicolumn{3}{|l|}{ Random-effects model } \\
\hline Infliximab $5 \mathrm{mg}$ vs placebo & $164.6(71.35,339.1)$ & $165(70.22,354.8)$ \\
\hline Ustekinumab $45 \mathrm{mg}$ vs placebo & $61.2(32.33,107)$ & $60.88(32.76,105.8)$ \\
\hline Ustekinumab $90 \mathrm{mg}$ vs placebo & $78.96(41.98,136.9)$ & $78.68(42.38,136.2)$ \\
\hline Ustekinumab $45 \mathrm{mg}$ vs infliximab $5 \mathrm{mg}$ & $0.4384(0.1464,0.9972)$ & $0.4395(0.1366,1.019)$ \\
\hline Ustekinumab $90 \mathrm{mg}$ vs infliximab $5 \mathrm{mg}$ & $0.5659(0.1874,1.286)$ & $0.567 \mid(0.1771,1.317)$ \\
\hline Ustekinumab $90 \mathrm{mg}$ vs ustekinumab $45 \mathrm{mg}$ & I.332 (0.786I, 2.I) & $1.336(0.7873,2.118)$ \\
\hline
\end{tabular}

Abbreviations: $\mathrm{Crl}$, credible interval; OR, odds ratio; PASI, psoriasis area and severity index.

\section{Publish your work in this journal}

Comparative Effectiveness Research is an international, peer reviewed open access journal focusing on comparative effectiveness of health care including preventative health care strategies, diagnostic strategies, diagnostic technology, medical devices, drugs, medical technology, health systems and organization. The manuscript management system is completely online and includes a very quick and fair peer-review system. Visit http://www.dovepress.com/testimonials.php to read real quotes from published authors.

Submit your manuscript here: http://www.dovepress.com/comparative-effectiveness-research-journal 